\title{
Isolation and characterization of two acaricidal compounds from Calpurnia aurea subsp. aurea (Fabaceae) leaf extract
}

\author{
Olubukola T. Adenubi ${ }^{1,3^{*}}$, Muna Ali Abdalla ${ }^{1}$, Aroke S. Ahmed ${ }^{1}$, Emmanuel M. Njoya ${ }^{1}$, Lyndy J. \\ McGaw $^{1}$, Jacobus N. Eloff ${ }^{1}$, Vinny Naidoo ${ }^{2 *}$ \\ ${ }^{1}$ Phytomedicine Programme, Department of Paraclinical Sciences, Faculty of Veterinary Sciences, University of \\ Pretoria, Onderstepoort 0110, South Africa. \\ ${ }^{2}$ Biomedical Research Centre, Faculty of Veterinary Sciences, University of Pretoria, Onderstepoort 0110, \\ South Africa.
}

${ }^{3}$ Permanent address: Department of Veterinary Physiology and Pharmacology, College of Veterinary Medicine, Federal University of Agriculture, PMB 2240 Alabata, Abeokuta, Ogun State, Nigeria.

\section{*Correspondence}

Olubukola Adenubi, Department of Veterinary Physiology and Pharmacology, College of Veterinary Medicine, Federal University of Agriculture, Abeokuta, Ogun State, Nigeria.

Telephone number: +234-8025409691; E-mail: bukiadenubi@gmail.com

ORCID: 0000-0003-3445-8485

\begin{abstract}
The menace caused by ticks and tick-borne diseases is a major limitation to the livestock industry in Africa. The high costs and non-availability of synthetic, chemical acaricides to resource-limited farmers, resistance of ticks to available acaricides and residue problems in meat and milk consumed by humans further complicate matters. The use of plant extracts as a possible source of new acaricides has received much interest in the last decade. In our endeavour to discover natural acaricidal compounds, tick toxicant bioassays were conducted and the chloroform fraction of Calpurnia aurea ethanol leaf extract had good acaricidal activity. Further purification of the fraction revealed two flavonoids, isolated from Calpurnia aurea for the first time. These flavonoids were characterized as apigenin-7-O- $\beta$-D-glycoside and isorhoifolin by means of NMR spectroscopic and mass spectrometry analysis. Isorhoifolin was the most potent compound $\left(\mathrm{LC}_{50}=0.65 \mathrm{mg} / \mathrm{ml}\right)$, was not cytotoxic and should be further investigated for its potential as an acaricidal agent.
\end{abstract}

Keywords Acaricidal activity. Plant extracts. Flavonoids. Apigenin-7-O- $\beta$-D-glycoside. Isorhoifolin 


\section{Introduction}

Ticks rank second only to mosquitoes as the most common vectors of diseases to animals and humans (Oberchain and Galun 2013). In addition, ticks are the direct causes of deadly tick paralysis, allergic reactions and toxicoses (Sonenshine and Roe 2013). Current tick control involves application of chemical acaricides, usually synthetic, but tick resistance and negative environmental impacts have become problematic from years of overuse. As such, the search for alternative control measures such as acaricidal or repellent medicinal plants is strongly advocated (Mondal et al. 2013).

Calpurnia aurea (Ait.) Benth. of the family Fabaceae, commonly called wild laburnum, is a small tree of about $4 \mathrm{~m}$, reaching up to $15 \mathrm{~m}$ under forest conditions. The plant is widely distributed in Africa from southern Africa (Eastern Cape through to KwaZulu-Natal, Mpumalanga, Gauteng, Limpopo and Swaziland) to Eritrea (the horn of Africa), stretching northwards to as far as Ethiopia and southern India (Getiye et al. 2016). In South Africa, the juice of crushed leaves, ground bark and roots of C. aurea are used to kill ectoparasites and to relieve itching while unspecified parts are used to destroy maggots. The acaricidal and tick attractant activities of the plant have been reported (Zorloni et al. 2010; Nana et al. 2010; Nana et al. 2015).

Previous screening was conducted to evaluate the acaricidal properties of some plant species selected based on their ethnoveterinary use against ticks in South Africa (Fouche et al. 2016; Wellington et al. 2017). They found that extracts of C. aurea had good acaricidal activities against larvae of Rhipicephalus (Boophilus) decoloratus (85\% tick mortality) and Rhipicephalus (Boophilus) microplus (100\% tick mortality). However, the bioactive compounds responsible for these observations have not been identified. This study aimed to isolate and characterize the acaricidal compounds in $C$. aurea using chromatographic and spectroscopic techniques respectively.

\section{Materials and Methods}

\section{Plant material}

Calpurnia aurea leaves were collected from the Lowveld National Botanical Garden, Nelspruit, Mpumalanga (GPS coordinates $25.444^{\circ} \mathrm{S}, 30.970^{\circ} \mathrm{E}$ ) on 29 January 2015 and a voucher specimen deposited at the H.G.W.J. Schweickerdt Herbarium, University of Pretoria (Specimen no: PRU 121520). The plant material was dried at room temperature (c. $25^{\circ} \mathrm{C}$ ) for two weeks in a well-ventilated room. Collection, drying and storage of the plant material were as outlined previously by McGaw and Eloff (2010). 


\section{Extraction and isolation procedure}

Dried and pulverised leaves of $C$. aurea $(423.48 \mathrm{~g})$ were extracted with ethanol $(4 \mathrm{~L})$ as described by Mukandiwa et al. (2013) to give $44.9 \mathrm{~g}$ of dry ethanol extract. This extract was dissolved in a mixture of chloroform and water and fractionated by solvent-solvent extraction to yield hexane ( $8.7 \mathrm{~g})$, chloroform (26.5 g), butanol (1.3 g), methanol/water (1.8 g) and water (1.2 g) (Eloff, 1998). The chloroform fraction was subjected to further separation via silica gel column chromatography. The column was eluted with chloroform:methanol (gradient 0 to $100 \%$ methanol) to afford four sub-fractions. Sub-fraction III showed interesting ultraviolet (UV) absorbing bands on thin layer chromatography (TLC), which turned to yellow with vanillin reagent. Accordingly, it was further refined using silica gel column chromatography. The process continued until two compounds were obtained in their pure forms.

\section{In vitro acaricidal bioassay}

\section{Ticks}

Adult Rhipicephalus turanicus ticks (both sexes) were obtained from Clinvet International, Bloemfontein, South Africa. The ticks were kept at the Phytomedicine laboratory, Faculty of Veterinary Sciences, University of Pretoria in glass humidity chambers at an average temperature of $25 \pm 1{ }^{\circ} \mathrm{C}$. Relative humidity was maintained at $75 \pm 10 \%$ by placing supersaturated sodium chloride solution in the glass chamber. The ticks were stored in vials covered with cotton mesh (to allow for air exchange) and set on a square glass plate placed at the base of the chamber on four small bearings. The four sides of the glass plate were $1.5 \mathrm{~cm}$ from the wall of the humidity chamber to prevent the ticks from reaching the walls.

\section{Experimental protocol}

Two-fold graded increasing concentrations $(3-100 \mathrm{mg} / \mathrm{ml}$ diluted in acetone) of the more non-polar fractions (chloroform, hexane and butanol) were used for adult immersion tests (Al- Rajhy et al. 2003). Ten adult ticks were immersed in each test solution for one minute, dried on Whatman No. 1 filter paper and kept at room temperature $\left(25 \pm 1^{\circ} \mathrm{C}\right)$ and $85 \%$ relative humidity in $20 \mathrm{ml}$ glass vials closed with a perforated stopper. Graded two-fold increasing concentrations of cypermethrin $(0.2-5 \mathrm{mg} / \mathrm{ml})$ served as the positive control while acetone was the negative control. Each extract concentration was tested in triplicate on each of three different occasions to yield nine replicates. Percentage mortality was determined 24 hours post treatment by viewing the ticks under a stereo microscope (American Optical Corporation). Ticks were confirmed dead based on signs of cuticle darkness, halted Malpighian tubule movement and haemorrhagic skin lesions. This bioassay was repeated in a 
subsequent experiment using the isolated compounds $(0.06-1 \mathrm{mg} / \mathrm{ml})$. Each concentration was tested in duplicate and the experiment was done once due to the limited quantity of the isolated compounds available.

\section{Cytotoxicity (in vitro safety) bioassay}

\section{Maintenance of cell lines}

Vero monkey kidney $\left(\mathrm{ATCC}^{\circledR} \mathrm{CCL}^{\circledR} 81^{\mathrm{TM}}\right.$ ) and HepG2 human liver cancer $\left(\mathrm{ATCC}^{\circledR}\right.$ HB-8065 ${ }^{\mathrm{TM}}$ ) cells were purchased from Cellonex, South Africa. Vero cells were maintained in Minimal Essential Medium (MEM, Whitehead Scientific, South Africa) containing $4.5 \mathrm{~g} / \mathrm{l}$ glucose and $4 \mathrm{mM}$ L-glutamine supplemented with $1 \%$ gentamicin and 5\% foetal calf serum (FCS, Highveld Biological, South Africa) while HepG2 cells were maintained in Dulbecco's Minimal Essential Medium (DMEM, Whitehead Scientific, South Africa) containing $4.5 \mathrm{~g} / \mathrm{l}$ glucose and $4 \mathrm{mM}$ L-glutamine supplemented with $10 \% \mathrm{FCS}$. Both cell types were maintained at $37^{\circ} \mathrm{C}$ in a $5 \% \mathrm{CO}_{2}$ incubator (Hera Cell 150 , Germany). Cells were passaged three times weekly by trypsinization with trypsin/ethylenediaminetetraacetic acid solution (Invitrogen, Cergy-Pontoise, France) into $75 \mathrm{~cm}^{2}$ culture flasks.

\section{Experimental protocol}

Viable cell growth after incubation of Vero and HepG2 cells with test samples was determined using the tetrazolium-based colorimetric MTT assay [3-(4, 5-dimethylthiazolyl-2)-2, 5-diphenyltetrazolium bromide] described by Mosmann (1983). Cells of a subconfluent culture were harvested and centrifuged at $200 \mathrm{x} g$ for 5 minutes and resuspended in growth medium (MEM for Vero cells and DMEM for HepG2 cells) to $10^{5}$ cells $/ \mathrm{ml}$. One hundred microliters $(100 \mu \mathrm{l})$ of the cell suspension was pipetted into each well of columns 2 to 11 of a sterile 96-well microtitre plate, then $200 \mu$ of MEM or DMEM was added to wells of columns 1 and 12 to minimize the "edge effect" and maintain humidity. The plates were incubated overnight at $37^{\circ} \mathrm{C}$ in a $5 \% \mathrm{CO}_{2}$ incubator to allow cells to attach to the bottom of the plates.

Test samples were dissolved in dimethyl sulphoxide (DMSO) to a concentration of $100 \mathrm{mg} / \mathrm{ml}$ and then diluted 100 -fold in culture medium for the concentration tested $(1000 \mu \mathrm{g} / \mathrm{ml})$. One hundred microliters $(100 \mu \mathrm{l})$ of decreasing concentrations of the test samples $(1000,750,500,250,100,50 \mu \mathrm{g} / \mathrm{ml})$ were added in the corresponding wells and the plates were again incubated at $37^{\circ} \mathrm{C}$ for 48 hours in the $5 \% \mathrm{CO}_{2}$ incubator. Untreated cells served as the negative control while doxorubicin hydrochloride (Pfizer Laboratories, South Africa) served as the positive control. After incubation, the growth medium was aspirated from the cells which were washed with $200 \mu$ phosphate buffered saline (PBS, Whitehead Scientific,) and replaced with $200 \mu 1$ of fresh medium and $30 \mu 1$ MTT (Sigma-Aldrich, South Africa; stock solution of $5 \mathrm{mg} / \mathrm{ml}$ in PBS). The plates were 
incubated further for 4 hours at $37^{\circ} \mathrm{C}$ in the $5 \% \mathrm{CO}_{2}$ incubator. After this, the growth medium in each well was carefully removed using a suction pump (Integra, USA), without disturbing the MTT formazan crystals. These crystals were dissolved by adding $50 \mu \mathrm{l}$ DMSO to each well and shaken gently for 2 minutes. The MTT reduction was measured immediately by detecting absorbance in a spectrophotometer (Biotek Synergy, USA) at a wavelength of $570 \mathrm{~nm}$ and a reference wavelength of $630 \mathrm{~nm}$. The wells in column 1, containing medium and MTT but no cells were used to blank the plate reader. The lethal concentration of test samples resulting in a 50\% reduction of absorbance $\left(\mathrm{LC}_{50}\right)$ compared to untreated cells was calculated. Each extract concentration was tested in quadruplicate and the assays repeated three times. This bioassay was repeated in a subsequent experiment using the isolated compounds $(5-100 \mu \mathrm{g} / \mathrm{ml})$.

\section{Structure identification of compounds}

Two compounds were identified by means of 1D and 2D NMR (spectroscopic and mass spectrometry analysis. ${ }^{1} \mathrm{H}$ NMR and 2D NMR experiments data were acquired on a $400 \mathrm{MHz}$ NMR spectrometer (Bruker Avance III $400 \mathrm{MHz}$. HPLC-HR-ESI-MS was performed on Waters Acquity Ultra Performance Liquid Chromatography (UPLC®) system hyphenated to a quadrupole-time-of-flight (QTOF) instrument.

\section{Data analysis}

Data on acaricidal activity and cytotoxicity were presented as the arithmetic mean values \pm standard error of mean. Significance was analysed using one-way analysis of variance followed by Tukey's multiple comparison test on GraphPad Prism 7.02 (GraphPad Software, San Diego-CA, USA). Values were considered to differ statistically when $\mathrm{p} \leq 0.05$. The $\mathrm{LC}_{50}$ and $\mathrm{LC}_{90}$ values for acaricidal activity were determined using the linear regression model.

\section{Results}

\section{Structure characterization of acaricidal compounds}

Two compounds, apigenin-7-O- $\beta$-D-glycoside (molecular formula $\mathrm{C}_{21} \mathrm{H}_{20} \mathrm{O}_{10}$ ) (Gulluce et al. 2015; Peng et al. 2016) and isorhoifolin (apigenin 7-O-rutinoside, 4',5,7-trihydroxyflavone 7-O-rutinoside; molecular formula $\mathrm{C}_{27} \mathrm{H}_{30} \mathrm{O}_{14}$ ) (Kokotkiewicz et al. 2012) (Fig. 1), were isolated as yellow powders, which gave strongly UV absorbing bands on TLC at $254 \mathrm{~nm}$ and turned to yellow with vanillin spray reagent. Their spectroscopic data agreed with published data (Kokotkiewicz et al. 2012; Peng et al. 2016). 


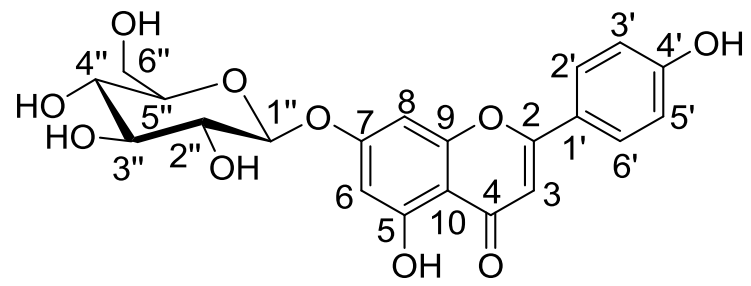

Apigenin-7-O- $\beta$-D-glycoside

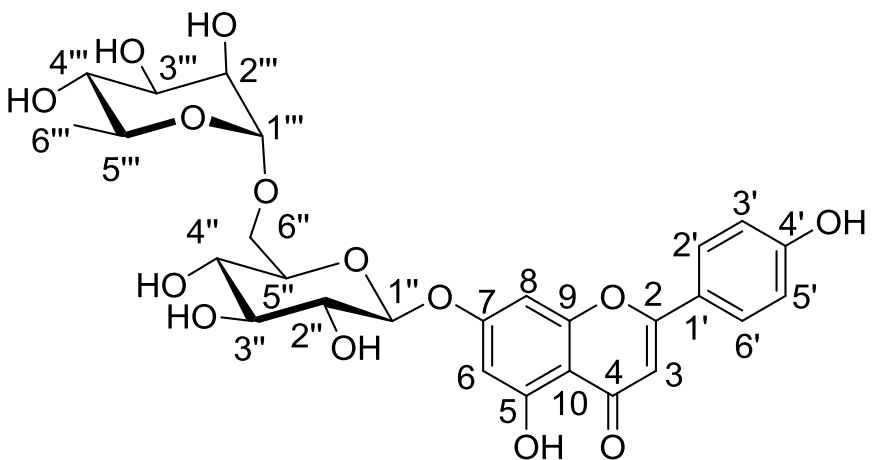

Isorhoifolin

Fig. 1 Apigenin-7-O- $\beta$-D-glycoside (molecular formula: $\mathrm{C}_{21} \mathrm{H}_{20} \mathrm{O}_{10}$ ) and isorhoifolin (molecular formula: $\mathrm{C}_{27} \mathrm{H}_{30} \mathrm{O}_{14}$ ) isolated from Calpurnia aurea

The ${ }^{1} \mathrm{H}$ NMR and ${ }^{13} \mathrm{C}$ NMR data are presented in Table 1. A search in the Dictionary of Natural Products (Chapman and Hall, 2017), the Chemical Abstracts Services (SciFinder) and comparing the spectroscopic data with available literature confirmed the structures. With respect to the coupling constant of the anomeric proton $(J=7.3 \mathrm{~Hz})$, the sugar is $\beta$-connected and should have (D)-configuration, according to the Klyne rule (Klyne, 1950).

Table $1{ }^{1} \mathrm{H}$ NMR and ${ }^{13} \mathrm{C}$ NMR data of apigenin-7- $O-\beta$-D-glycoside and isorhoifolin (in DMSO- $d_{6}$ )

\begin{tabular}{|c|c|c|c|c|}
\hline \multirow[t]{2}{*}{ Position } & \multicolumn{2}{|l|}{ Apigenin-7-O- $\beta$-D-glycoside } & \multicolumn{2}{|l|}{ Isorhoifolin } \\
\hline & $\mathrm{H}$ & $\mathrm{C}$ & $\mathrm{H}$ & $\mathrm{C}$ \\
\hline 2 & - & 165.5 & - & 165.5 \\
\hline 3 & $6.87, \mathrm{~s}$ & 103.5 & $6.87, \mathrm{~s}$ & 104.0 \\
\hline 4 & - & 182.0 & - & 182.0 \\
\hline 5 & & 162.5 & - & 161.5 \\
\hline 6 & $6.45, \mathrm{~s}$ & 100.0 & $6.45, \mathrm{~s}$ & 100.0 \\
\hline 7 & - & 163.5 & - & 163.5 \\
\hline 8 & $6.83, \mathrm{~s}$ & 95.8 & $6.77, \mathrm{~s}$ & 95.5 \\
\hline 9 & - & 157.5 & - & 157.5 \\
\hline 10 & - & 106.0 & - & 106.0 \\
\hline $1^{\prime}$ & - & 121.5 & - & 121.5 \\
\hline $2^{\prime}, 6^{\prime}$ & $7.95, \mathrm{~d}, J=8.7 \mathrm{~Hz}$ & 129.5 & $7.95, \mathrm{~d}, J=8.7 \mathrm{~Hz}$ & 129.5 \\
\hline $3^{\prime}, 5^{\prime}$ & $6.95, \mathrm{~d}, J=8.7 \mathrm{~Hz}$ & 116.5 & $6.95, \mathrm{~d}, J=8.7 \mathrm{~Hz}$ & 116.5 \\
\hline $4^{\prime}$ & - & 162.7 & - & 162.0 \\
\hline $1 "$ & $4.92, \mathrm{~d}, J=7.3 \mathrm{~Hz}$ & 100.2 & $5.06, \mathrm{~d}, J=7.3 \mathrm{~Hz}$ & 100.5 \\
\hline $2^{\prime \prime}$ & $3.31, \mathrm{~m}$ & 73.6 & $3.30, \mathrm{~m}$ & 74.0 \\
\hline $3 "$ & $3.28, \mathrm{~m}$ & 77.3 & $3.28, \mathrm{~m}$ & 77.0 \\
\hline $4 "$ & $3.20, \mathrm{~m}$ & 70.0 & $3.15, \mathrm{~m}$ & 70.5 \\
\hline $5^{\prime \prime}$ & $3.33, \mathrm{~m}$ & 77.0 & $3.59, \mathrm{~m}$ & 76.5 \\
\hline $6 "$ & $3.71, \mathrm{~d}, J=11.2 \mathrm{~Hz}, \mathrm{Ha}-6 "$ & 61.0 & $3.84, \mathrm{~d}, J=10.9 \mathrm{~Hz}, \mathrm{Ha}-6 "$ & 66.0 \\
\hline & $3.51, \mathrm{~d}, J=11.2 \mathrm{~Hz}, \mathrm{Hb}-6 "$ & & $3.41, \mathrm{~m}, \mathrm{Hb}-6 "$ & \\
\hline $1 " '$ & & & $4.54, \mathrm{~s}$ & 101.0 \\
\hline $2^{\prime \prime \prime}$ & & & 3.64 , brs & 71.0 \\
\hline $3^{\prime \prime \prime}$ & & & $3.41, \mathrm{~m}$ & 71.5 \\
\hline $4 " '$ & & & $3.13, \mathrm{~m}$ & 72.5 \\
\hline $5^{\prime \prime \prime}$ & & & $3.46, \mathrm{~m}$ & 69.0 \\
\hline 6"' & & & $1.07, \mathrm{~d}, J=6.1 \mathrm{~Hz}$ & 17.8 \\
\hline
\end{tabular}




\section{In vitro acaricidal activity}

The chloroform fraction of $C$. aurea was the most active fraction followed by hexane fraction and butanol fraction. The $\mathrm{LC}_{50}$ and $\mathrm{LC}_{90}$ values were $28.64,21.53,65.09 \mathrm{mg} / \mathrm{ml} ; 102.74,81.23$ and $173.45 \mathrm{mg} / \mathrm{ml}$ respectively (Table 2). Two flavonoid compounds, apigenin-7-O- $\beta$-D-glycoside and isorhoifolin, at a concentration of $1 \mathrm{mg} / \mathrm{ml}$ had $\mathrm{LC}_{50}$ and $\mathrm{LC}_{90}$ values of 1.35 and $0.65 \mathrm{mg} / \mathrm{ml} ; 3.95$ and $1.71 \mathrm{mg} / \mathrm{ml} \mathrm{respectively}$ compared with the $\mathrm{LC}_{50}$ and $\mathrm{LC}_{90}$ values value of cypermethrin ( 0.6 and $1.09 \mathrm{mg} / \mathrm{ml}$ respectively).

Table 2 Acaricidal activity $\left(\mathrm{LC}_{50}\right.$ and $\mathrm{LC}_{90}$ in $\left.\mathrm{mg} / \mathrm{ml}\right)$ of the fractions and isolated compounds from Calpurnia aurea against Rhipicephalus turanicus ticks after 24 hours

\begin{tabular}{lll}
\hline & $\begin{array}{ll}\mathbf{L C}_{\mathbf{5 0}}(\mathbf{m g} / \mathbf{m l}) \\
\text { Mean } \pm \text { SEM }\end{array}$ & $\begin{array}{l}\mathbf{L C}_{\mathbf{9 0}}(\mathbf{m g} / \mathbf{m l}) \\
\text { Mean } \pm \text { SEM }\end{array}$ \\
\hline Hexane fraction & $21.53 \pm 1$ & $81.23 \pm 9$ \\
Butanol fraction & $65.09 \pm 10$ & $173.45 \pm 65$ \\
Chloroform fraction & $28.64 \pm 13$ & $102.74 \pm 59$ \\
Apigenin-7-O- $\beta$-D-glycoside & $1.35 \pm 0.2$ & $3.95 \pm 1$ \\
Isorhoifolin & $0.65 \pm 0.1$ & $1.71 \pm 0.1$ \\
Cypermethrin (positive control) & 0.6 & $1.09 \pm 0.10$ \\
\hline
\end{tabular}

\section{Cytotoxicity}

For toxicity, we used a cut-off of $100 \mu \mathrm{g} / \mathrm{ml}$ as an indicator for toxicity (Nondo et al. 2015). Based on this criterion, most of the fractions and isolated compounds were non-toxic to Vero and HepG2 cells, with the exception of the chloroform fraction with $\mathrm{LC}_{50}$ of $76 \mu \mathrm{g} / \mathrm{ml}$ for HepG2 cells. In comparison, doxorubicin had $\mathrm{LC}_{50}$ of $5.03 \pm 6.39$ and $0.18 \pm 0.05 \mu \mathrm{M}$ against Vero and HepG2 cells respectively (Table 3). 
Table 3 Cytotoxicity $\left(\mathrm{LC}_{50}\right.$ in $\left.\mu \mathrm{g} / \mathrm{ml}\right)$ of the crude extract, fractions and isolated compounds from Calpurnia aurea against Vero and HepG2 cells

\begin{tabular}{lll}
\hline Calpurnia aurea plant & \multicolumn{2}{c}{ Cytotoxicity $\mathbf{L C}_{\mathbf{5 0}}(\boldsymbol{\mu} \mathbf{g} / \mathbf{m l}) \mathbf{+ S E M}$} \\
& Vero cells & HepG2 cells \\
\hline Crude extract & $623 \pm 4$ & $123 \pm 11$ \\
Chloroform fraction & $428 \pm 9$ & $76 \pm 13$ \\
Butanol fraction & $>1000$ & $>1000$ \\
Hexane fraction & $499 \pm 10$ & $337 \pm 5$ \\
Water fraction & $>1000$ & $>1000$ \\
Methanol/Water fraction & $>1000$ & $934 \pm 6$ \\
Apigenin-7- $O$ - $\beta$-D-glycoside & $>100$ & $73 \pm 1$ \\
Isorhoifolin & $>100$ & $72 \pm 5$ \\
Doxorubicin (positive control, $\mu \mathrm{M})$ & $5.03 \pm 6.4$ & $0.18 \pm 0.1$ \\
\hline
\end{tabular}

\section{Discussion}

Solvent-solvent fractionation of the crude ethanol extract of the leaves of $C$. aurea gave five fractions (hexane, chloroform, butanol, methanol/water and water) based on solubility characteristics of the constituents. The chloroform fraction afforded two acaricidal compounds, identified as apigenin-7- $O$ - $\beta$-D-glycoside and isorhoifolin (apigenin-7-O-rutinoside). Apigenin-7-O- $\beta$-D-glycoside is a glycosyloxyflavone, that is, apigenin substituted by a $\beta$-D-glucopyranosyl moiety at position 7 via a glycosidic linkage. This compound, while identified for the first time from $C$. aurea, has been previously identified in other plants such as Pteris multifida Poir. (Pteridaceae), Marrubium globosum Montbret \& Aucher ex Benth (Lamiaceae), Elsholtzia splendens Nakai ex F.Maek. (Lamiaceae), Stevia rebaudiana (Bertoni) Bertoni (Asteraceae), Lonicera gracilipes var glandulosa (Caprifoliaceae) and Humulus scandens L. (Cannabaceae) (Chen et al. 2011; Wölwer-Rieck, 2012; Peng et al. 2016). Isorhoifolin has been found in many Citrus species such as Citrus paradisi Macfad (Rutaceae), Mentha species (Lamiaceae), Teurium polium var. gnapholodes (Lamiaceae) and Cynara scolymus L. (Cynareae) (Nassar et al. 2013; Boghrati et al. 2016; Hawryl et al. 2016).

Flavonoids have been reported to have significant antiparasitic activities. Their effects on arthropods have been reported to involve repellency (Habeeb, 2010), inhibition of feeding, developmental disorders, deformation, infertility, inhibition of oviposition (Ghosh et al. 2015) or death (Dantas et al. 2015). The potential role of flavonoids in the modulation of reproductive activity of ticks was reported by Ravindran et al. (2011) and 
Juliet et al. (2012), where $1.56 \mathrm{mg} / \mathrm{ml}$ of Leucas aspera L. and $50 \mathrm{mg} / \mathrm{ml}$ of Jatropha curcas $\mathrm{L}$. produced 100 and $90 \%$ failure of eclosion of eggs respectively. This was attributed to acacetin and apigenin isolated from $L$. aspera and flavone apigenins (apigenin 7-O- $\beta$-D-neohesperidoside, apigenin 7-O- $\beta$-D-galactoside), orientin, vitexin, vicenin II and the biflavone di-C- $\beta$-Dglucopyranoside-methylene-( $\left.8,8^{\prime}\right)$-biapigenin isolated from the leaves of J. curcas (Abd-Alla et al. 2009). The presence of apigenin and luteolin in Lippia javanica Burm F. Spreng tested at $50 \mathrm{mg} / \mathrm{ml}$ may have contributed to the $92 \%$ adult tick mortality reported by Madzimure et al. (2011). The $\mathrm{LC}_{50}$ value of $0.65 \mathrm{mg} / \mathrm{ml}$ for isorhoifolin compares favourably with some known acaricidal compounds isolated from plants. This makes flavonoids an interesting group of study molecules for acaricidal activity.

To verify the safe use of the fractions and isolated compounds from $C$. aurea, cytotoxicity tests were undertaken against two mammalian cell lines. These cell-line tests showed the two compounds to be toxicologically acceptable within the limits of concentration tested.

\section{Conclusions}

New classes of acaricides are urgently required and plant flavonoids represent a novel set of potential lead structures. Although the use of plant extracts to control ticks is common in impoverished communities, the possibility of discovering a compound that may become a new acaricide should not be ignored. Further work is required to characterize the true acaricidal activities of apigenin-7-O- $\beta-\mathrm{D}$-glycoside and isorhoifolin.

\section{Acknowledgements}

Financial support from the Technology Innovation Agency in conjunction with the Council for Scientific and Industrial Research, University of Pretoria and the Schlumberger Faculty for the Future Foundation is thankfully acknowledged.

\section{References}

Abd-Alla HI, Moharram FA, Gaara AH, El-Safty MM (2009) Phytoconstituents of Jatropha curcas L. leaves and their immunomodulatory activity on humoral and cell-mediated immune response in chicks. $\mathrm{Z}$ Naturforsch C 64 (7-8): 495-501. https://doi.org/10.1515/znc-2009-7-805

Al- Rajhy DH, Alahmed AM, Hussein HI, Kheir SM (2003) Acaricidal effects of cardiac glycosides, azadirachtin and neem oil against the camel tick, Hyalomma dromedarii (Acari: Ixodidae). Pest Manag Sci 59 (11): 1250-1254. https://onlinelibrary.wiley.com/doi/full/10.1002/748 
Boghrati Z, Naseri M, Rezaie M, Pham N., Quinn RJ, Tayarani-Najaran Z, Iranshahi M (2016) Tyrosinase inhibitory properties of phenylpropanoid glycosides and flavonoids from Teucrium polium L. var. gnaphalodes. Iran J Basic Med Sci 19 (8): 804. https://www.ncbi.nlm.nih.gov/PMC/articles/PMC5048114/

Chapman, Hall, (2017). Dictionary of Natural Products on CD-ROM, Chemical DataBase.

Chen Z, Ying X, Meng S, Zhu X, Jiang H, Cao Q, Li X, Meng, F (2011) High-performance liquid chromatographic determination and pharmacokinetic study of apigenin-7-O- $\beta$-D-glucoside in rat plasma after intravenous administration. Arch Pharm $\quad$ Res $34 \quad$ (5): 741-746. https://link.springer.com/article/10.1007/s12272-011-0507-3

Dantas A, Machado D, Araujo A, Oliveira-Junior R, Lima-Saraiva S, Ribeiro L, Almeida J, Horta M (2015) Acaricidal activity of extracts from the leaves and aerial parts of Neoglaziovia variegata (Bromeliaceae) on the cattle tick Rhipicephalus (Boophilus) microplus. Res Vet Sci 100: 165-168. https://doi.org/10.1016/j.rvsc.2015.04.012

Eloff J (1998) Which extractant should be used for the screening and isolation of antimicrobial components from plants? J Ethnopharm 60 (1): 1-8. https://doi.org/10.1016/s0378-8741(97)00123-2

Fouche G, Ramafuthula M, Maselela V, Mokoena M, Senabe J, Leboho T, Sakong BM, Adenubi OT, Eloff JN, Wellington KW (2016) Acaricidal activity of the organic extracts of thirteen South African plants against Rhipicephalus (Boophilus) decoloratus (Acari: Ixodidae). Vet Parasitol 224: 39-43. https://doi.org/10.1016/j.vet.par.2016.05.011

Getiye Y, Tolessa T, Engidawork E (2016) Antihypertensive activity of $80 \%$ methanol seed extract of Calpurnia aurea (Ait.) Benth. subsp. aurea (Fabaceae) is mediated through calcium antagonism induced vasodilation. J Ethnopharm 189: 99-106. https://doi.org/10.1016/j.jep.2016.04.056

Ghosh S, Tiwari SS, Kumar B, Srivastava S, Sharma AK, Kumar S, Bandyopadhyay A, Julliet S, Kumar R, Rawat AKS (2015) Identification of potential plant extracts for anti-tick activity against acaricide resistant cattle ticks, Rhipicephalus (Boophilus) microplus (Acari: Ixodidae). Exp Appl Acarol 66(1): 159-171. https://doi.org/10.1007/s10493-015-9890-7

Gulluce M, Orhan F, Yanmis D, Arasoglu T, Guvenalp Z, Demirezer LO (2015) Isolation of a flavonoid, apigenin 7-O-glucoside, from Mentha longifolia (L.) Hudson subspecies longifolia and its genotoxic potency. Toxicol Ind Health 31(9): 831-840. https://doi.org/10.1177/0748233713475511 
Habeeb SM (2010) Ethno-veterinary and medical knowledge of crude plant extracts and its methods of application (traditional and modern) for tick control. World Appl Sci J 11(9): 1047-1054. https://www.researchgate.net/publication/282150838

Hawryl MA, Niemiec MA, Slomka K, Waksmundzka-Hajnos M, Szymczak G (2016) Two-dimensional microTLC phenolic fingerprints of selected Mentha sp. on cyano-bonded polar stationary phase. J Chromatogr Sci 54 (1): 64-69. https://doi.org/10.1093/chromsci/bmv093

Juliet S, Ravindran R, Ramankutty SA, Gopalan AKK, Nair SN, Kavillimakkil AK, Bandyopadhyay A, Rawat AKS, Ghosh S (2012) Jatropha curcas (Linn) leaf extract-a possible alternative for population control of Rhipicephalus (Boophilus) annulatus. Asian Pac J Trop Dis 2 (3): 225-229. https://doi.org/10.1016/S2222$1808(12) 60051-6$

Klyne W (1950) The configuration of the anomeric carbon atoms in some cardiac glycosides. Biochem J 47 (4): xli-ii. https://ci.nii-ac.jp/naid/100306381691

Kokotkiewicz A, Luczkiewicz M, Sowinski P, Glod D, Gorynski K, Bucinski A (2012) Isolation and structure elucidation of phenolic compounds from Cyclopia subternata Vogel (honeybush) intact plant and in vitro cultures. Food Chem 133: 1373-1382. https://doi.org/10.1016/j.foodchem.2012.01.114

Madzimure J, Nyahangare ET, Hamudikuwanda H, Hove T, Stevenson PC, Belmain SR, Mvumi BM (2011) Acaricidal efficacy against cattle ticks and acute oral toxicity of Lippia javanica (Burm F.) Spreng. Trop Anim Health Prod 43 (2): 481-489. https://doi.org/10.1007/s11250-010-9720-1

McGaw LJ, Eloff JN (2010) Methods for evaluating efficacy of ethnoveterinary medicinal plants. In Ethnoveterinary Botanical Medicine: Herbal Medicines for Animal Health pp 1-24. https://books.google.com.ng/

Mondal D, Sarma K, Saravanan M (2013) Upcoming of the integrated tick control program of ruminants with special emphasis on livestock farming system in India. Ticks Tick Borne Dis 4: 1-10. https://doi.org/10.1016/j.ttbdis.2012.05.006

Mosmann T (1983) Rapid colorimetric assay for cellular growth and survival: application to proliferation and cytotoxicity assays. J Immunol Methods 65 (1-2): 55-63. https://doi.org/10.1016/0022-1759(83)90303-4

Mukandiwa L, Ahmed A, Naidoo V, Eloff JN (2013) Isolation of seselin isolated from Clausena anisata (Rutaceae) leaves and its effects on the feeding and development of Lucilia cuprina larvae may explain its the use in ethnoveterinary medicine to treat myiasis. J Ethnopharm 150: 886-891. https://doi.org/10.1016/j.jep.2013.09.037 
Nana P, Maniania N, Maranga R, Kutima H, Boga H, Nchu F, Eloff J (2010) Attraction response of adult Rhipicephalus appendiculatus and Rhipicephalus pulchellus (Acari: Ixodidae) ticks to extracts from Calpurnia aurea (Fabaceae). Vet Parasitol 174 (1): 124-130. https://doi.org/10.1016/j.vetpar.2010.08.016

Nana P, Nchu F, Ekesi S, Boga HI, Kamtchouing P, Maniania NK (2015) Efficacy of spot-spray application of Metarhizium anisopliae formulated in emulsifiable extract of Calpurnia aurea in attracting and infecting adult Rhipicephalus appendiculatus ticks in semi-field experiments. J Pest Sci 88 (3): 613-619. https://doi.org/10.1007/s10340-014-0637-8

Nassar MI, Mohamed TK, Elshamy AI, El- Toumy SA, Lateef AMA, Farrag AH (2013) Chemical constituents and anti- ulcerogenic potential of the scales of Cynara scolymus (artichoke) heads. J Sci Food Agric 93 (10): 2494-2501. https://doi.org/10.1002/jsfa.6065

Nondo RS, Moshi MJ, Erasto P, Zofou D, Njouendou AJ, Wanji S, Ngemenya MN, Kidukuli AW, Masimba PJ, Titanji VP (2015) Evaluation of the cytotoxic activity of extracts from medicinal plants used for the treatment of malaria in Kagera and Lindi regions, Tanzania. https://imsear.hellis.org/handle/123456789/159160

Obenchain FD, Galun R (2013) Physiology of Ticks: Current Themes in Tropical Science. Elsevier, 1-501. https://scholar.google.com/

Peng HY, Zhang XH, Xu JZ (2016) Apigenin-7-O- $\beta$-D-glycoside isolation from the highly copper-tolerant plant Elsholtzia splendens. J Zhejiang Univ Sci B 17 (6): 447-454. https://doi.org/10.1631/jzus.B1500242

Ravindran R, Juliet S, Sunil A, Kumar KA, Nair SN, Amithamol K, Shynu M, Rawat AKS, Ghosh S (2011) Eclosion blocking effect of ethanolic extract of Leucas aspera (Lamiaceae) on Rhipicephalus (Boophilus) annulatus. Vet Parasitol 179 (1): 287-290. https://doi.org/10.1016/j.vetpar.2011.02.021

Sonenshine DE, Roe RM (2013) Overview: ticks, people and animals. In: Sonenshine DE, Roe RM (eds) The biology of ticks, vol 1. Oxford University Press, New York. https://books.google.com.ng/

Wellington KW, Leboho T, Sakong BM, Adenubi OT, Eloff JN, Fouche G (2017) Further studies on South African plants: Acaricidal activity of organic plant extracts against Rhipicephalus (Boophilus) microplus (Acari: Ixodidae). Vet Parasitol 234: 10-12. https://doi.org/10.1016/j.vetpar.2016.12.014

Wölwer-Rieck U (2012) The leaves of Stevia rebaudiana (Bertoni), their constituents and the analyses thereof: a review. J Agric Food Chem 60 (4): 886-895. https://doi.org/10.1021/jf.2044907

Zorloni A, Penzhorn BL, Eloff JN (2010) Extracts of Calpurnia aurea leaves from southern Ethiopia attract and immobilise or kill ticks. Vet Parasitol 168: 160-164. https://doi.org/10.1016/j.vetpar.2009.10.026 